\title{
2 Point-to-point: telecommunications networks from the optical telegraph to the mobile telephone
}

\begin{abstract}
This chapter surveys the history of telecommunications from a global perspective and highlights three influential interpretative traditions. It has two parts. The first part defines "telecommunications" and sketches the main dimensions of four telecommunications networks over a two-hundred-year period - the optical telegraph, the electric telegraph, the landline telephone, and the mobile telephone (and its predecessor, the wireless telegraph). The second part shows how historical scholarship on topics in the history of telecommunications has been shaped by three intellectual traditions: the Large Technical Systems (LTS) approach; political economy; and the Social Construction of Technology (SCOT).
\end{abstract}

Keywords: history of communications, telecommunications, optical telegraph, electric telegraph, wireless telegraph, radio, telephone, mobile telephone, Large Technical Systems (LTS), political economy

Every generation writes its own history. The history of telecommunications is no exception. Our goal in this essay is to survey a familiar topic from an innovative perspective. Our perspective is innovative in a dual sense: the temporal span is unusually long (1790s-present) and the spatial boundaries extend beyond Europe and North America. Telecommunications is an interpretative construct that historians use to group certain communications networks under a common rubric. The rationale for this essay is the subtle but fundamental shift in the character and significance of these networks that has been hastened by the recent emergence of the mobile telephone. In the past few decades, the mobile telephone has become ubiquitous not only in Europe and North America, the seedbed for all prior innovations in telecommunications, but also in many parts of Africa, Asia, and South America, regions in which, prior to the mobile telephone, access to telecommunications had been limited, if not altogether absent.

The word "telecommunications" is a French neologism that was invented long after three of the communications networks with which it has today come to be linked. The word itself, which means, literally "communications at a distance", was the brainchild of a French postal administrator, Édouard Estaunié, who coined

\footnotetext{
* In the preparation of this essay, we are grateful for the assistance of Colin Agur, Caroline Chen, Dwayne Winseck, and Nancy R. John.
} 
it in 1904 as a convenient catchphrase to lump together the landline telephone and the electric telegraph (Huurdeman 2003; John 2010). Estaunié's construct would not gain wide acceptance in France until the 1920s, and would remain largely unknown in the rest of Europe until 1932, when it was included in the official title of a newly reorganized regulatory agency, the International Telecommunication Union (or ITU). In the United States, the word was infrequently used (for a rare exception, see Herring \& Gross 1936) until after the Second World War (John 2010: 12-13). Today, of course, historians of communications use this construct as an umbrella term for a variety of communications networks that often include, in addition to the electric telegraph and the landline telephone, the optical telegraph, radio, television, the satellite, the mobile telephone, and the Internet (Noam 1992; Huurdeman 2003).

It may well be a fool's errand to lend coherence to such an amorphous construct. In this essay, we will try. It is our contention that the word telecommunications is best reserved for a limited, yet extremely important, constellation of longdistance communications networks that transmit messages from point to point. We use the term "network" - rather than possible alternatives, such as "media" or "system" - deliberately. The network form, as analyzed by scholars such as the Spanish-born historical sociologist Manuel Castells (Castells 1996-1998), the French political scientist Pierre Musso (Musso 1997), and the Hungarian-born physicist László Barabási (Barabási 2002), most accurately characterizes the defining features of this construct.

Telecommunications networks have three main features (Balbi 2013a). The first of these features concerns users. Telecommunications is a point-to-point (one-toone) network that makes it possible to establish a unique link between a relatively small number of nodes (as few as two). A key dimension of this feature is privacy: the exchange of information within a small group (or between two individuals) is predicated on the assumption, which in our age of digitally mediated communication is often mistaken, that this information is not widely shared. Indeed, it is often assumed that the communication is secret. This feature excludes radio and television, which are broadcast (many-to-many) networks rather than point-topoint (one-to-one) networks. Radio and television are designed to reach mass audiences, rather than niche audiences. Publicity, and not secrecy, is the goal. (For an alternative, more capacious definition, see McChesney 1993). The second feature concerns transmission. Telecommunications networks do not transmit a physical message, but, rather, a coded signal that represents the message. This signal is encoded at a network node, transmitted through the network, and decoded at a network node. This feature excludes the mail, which transmits physical messages, rather than signals (John 1995), but includes the electric telegraph, even though it often combined the physical transportation of messages from a sender to a transmitting office with its electrical transmission from office to office (Downey 2002). The third feature concerns directionality. Telecommunications networks enable the 
recipient to respond to a message in a timely fashion, and in the case of the landline and mobile telephone, instantaneously. They are, in a word, interactive. This feature excludes individualized broadcast media, such as email blasts, livestreaming, and on-line video.

While this definition is provisional, we believe it can help us to shift the longstanding focus of media scholarship from radio and TV broadcasting, media that many twentieth-century historians of communications assumed to represent the wave of the future, toward telecommunications, a medium that, at the moment, is in the ascendency not only in Europe and North America, but also in much of the rest of the world.

The essay has two parts. First, we sketch from our innovative perspective certain features of the history of four telecommunications networks - the optical telegraph, the electric telegraph, the landline telephone, and the mobile telephone (and its predecessor, the wireless telegraph). Second, we show how our perspective has been informed by three academic traditions that have proved influential in promoting historical understanding of these networks in the past, and that we believe will continue to prove useful in charting their evolution in the future.

\section{Historical overview}

While mid-twentieth-century communications historians typically trivialized the optical telegraph (Carey 1989), a consensus has emerged since the 1990s that it deserves pride of place as the first telecommunications network (John 2013). The idea of an optical telegraph originated in the eighteenth century. Like "telecommunications", the word was a French neologism (from the Greek: têle = distance and graphe $=$ writing). The first optical telegraphs were built almost simultaneously in the 1790s in Sweden and France (Wilson 1976; Flichy 1991; Holzmann \& Pehrson 1995; Headrick 2000: Ch. 6; Matterlart 1992, 2000; Rosenfeld 2001: 199-203). The Swedish optical telegraph was the brainchild of the Finnish-born poet Abraham N. Edelcrantz; in France, its primary champion was Claude Chappe, a cleric who had been deprived of his benefice during the French Revolution. Chappe demonstrated his invention in 1792; it went into operation two years later, the event that historians of communications typically regard as the beginnings of telecommunications (Matterlart 2000). The French optical telegraph remained in operation for some decades following the commercialization of the electric telegraph in Great Britain (1839) and the United States (1845). In 1852, it linked 556 towers in a Parisbased hub-and-spoke network that extended over 2,900 miles (John 2010: 14).

The optical telegraph utilized only one technical contrivance (the telescope) that would have been unknown to the ancients. The novelty of this medium lay in its combination in a single ensemble of three distinct elements: a network of signal towers, a technical apparatus to relay coded signals from tower to tower, 
and a code book that translated short phrases into a numerical form. In so doing, it provided government administrators with a fast and reliable tool for coordinating administrative and military operations. The French optical telegraph was built before Napoleon came to power, yet it was Napoleon who most fully demonstrated its utility, using it to coordinate his armies in the field. To this day, it remains, along with the guillotine, interchangeable parts, and the metric system, one of the most consequential inventions to have been spawned by the French Revolution.

Though the optical telegraph relied for its motive power on human labor rather than electricity, it fits our criteria for a telecommunications network. That is, it transmitted coded signals rather than physical messages from one point to another in either direction. The French optical telegraph was built by and for the French government and was closed to merchants. In other countries, different arrangements prevailed. In Great Britain and the United States, for example, optical telegraphs were built to facilitate the point-to-point circulation of information on market trends (Wilson 1976; John 2010: 16-17). Unlike the French optical telegraph, these networks were open to the public and patronized largely by merchants. Yet it was the French optical telegraph that remains the best known and that has dominated historical scholarship on this topic.

The electric telegraph is often hailed as a major technical breakthrough. This is not surprising. Along with electroplating, it was the first major practical application of electricity. Yet as a communications network, it was, as its name suggests, merely an incremental advance over the optical telegraph.

The similarities between the electric telegraph and the optical telegraph were self-evident to Samuel F. B. Morse, the American portrait-painter turned-electrictelegraph promoter who in 1840 obtained the first U.S. electric telegraph patent. In fact, Morse modeled two components of his original prototype on its optical precursor. Like the French optical telegraph, Morse's original prototype compressed messages by employing an elaborate numerical codebook; and like the French optical telegraph, Morse's original prototype was designed to minimize the likelihood of sabotage. By burying wires underground instead of stringing them overhead, Morse hoped to build a network as secure as the French government's fortified signal towers (John 2010: Ch. 2). When each of these components proved unworkable, Morse improvised. The numerical codebook was slow and complicated and the underground burial of wires was expensive and unreliable. As an alternative, Morse strung wires overhead and devised a letter-based binary signaling scheme - the eponymous Morse code - which is often regarded as a precursor to the binary language of the digital computer.

The electric telegraph had by 1840 already been commercialized in Great Britain, as a result of the creative collaboration of inventor William Fothergill Cooke and scientist Charles Wheatstone (Kieve 1973). Yet Morse's name would forever after be linked with the new medium. This was partly due to the widespread global adoption of Morse code and partly due to the publicity his anxious financial back- 
ers lavished on his invention. The electric telegraph in Great Britain found a ready market in the railroad sector, where it was rapidly adopted to coordinate the scheduling of trains. In the United States, in contrast, railroad managers were much slower to recognize its potential. Had they been quicker to adopt the new medium, Morse's electric telegraph might well have been less aggressively hyped (John 2010: Ch. 2).

The electric telegraph in Great Britain, the United States, and many other countries eventually became an important adjunct to business, journalism, and the military (Matterlart 1992; Blondheim 1994; Mattelart 2000; Hermans \& De Wit 2004; Hochfelder 2012). The network was widely used to consolidate imperial authority, and, in conjunction with the underwater cable - a related, yet distinct invention - would become an indispensable instrument of command and control for the leading colonial powers: Great Britain, France, and Japan (Headrick 1988, 1992; Noam 1999; Winseck \& Pike 2007; Yang 2011). In countries such as China and the Ottoman Empire, which were never formally colonized, it became a major agent of economic development (Baark 1997; Bektas 2000). By 1870, most of the world's electric telegraph networks had become government monopolies. The principal exceptions were the international cable network, which for commercial and diplomatic reasons remained privately owned and operated (Headrick 1992), and the domestic electric telegraph network in the United States, which for political reasons remained privately owned (John 2010; Wolff 2013).

Outside of the United States, the electric telegraph would remain the most influential telecommunications network from the 1840s until the Second World War. In the United States, however, a third telecommunications network - the landline telephone - would eclipse the telegraph by the First World War.

The landline telephone was commercialized in the 1870s, following the nearsimultaneous invention by several different people of a technical contrivance that was capable of transforming the human voice into a coded signal. Though the landline telephone was often hailed as a long-distance medium, for many decades following its commercialization it was used primarily for short-distance communications that were typically confined to a specific locality (Armstrong \& Nelles, 1986; Weiman 2003; Calvo 2006; John 2010). This was true not only in small towns, but also in giant cities. The average distance of a telephone call originating in Chicago, Illinois, in 1900, for example, was a mere 3.4 miles (John 2010: 283).

The regulation of the landline telephone varied from place to place. In North America, the principal regulatory domain was local. Operating companies held municipal franchises that typically specified rates and limited entry. These franchises were modeled on the charters granted to gas works and water plants and had little to do with the regulations that had been devised for the electric telegraph (Armstrong \& Nelles 1986; Horwitz 1989; Gabel 1995; Weiman 2003; John 2010).

In Europe, in contrast, the legacy of the electric telegraph was more direct. Most electric telegraphs were government owned and operated, and this circum- 
stance cast a long shadow on the regulation of the landline telephone. In Great Britain, Spain, France, Switzerland and Italy, the government initially granted concessions to private ventures, before deciding to nationalize all or part of the network, a task that for technical, administrative, and financial reasons proved enormously challenging (Hazlewood 1953; Kobelt 1980; Bertho-Lavenir 1981, 1988; Calvo 2002; Millward 2005; Wallsten 2005; Balbi 2011). In the Scandinavian countries and the Netherlands, in contrast, governments permitted ownership and operation of the local network, but retained control over the long-distance network (De Wit 1998; Helgesson 1999; Millward 2005; Wallsten 2005). Finally, in Germany, Greece, and Romania, the government owned and operated the network from the start (Thomas 1988; Schneider 1991; Millward 2005; Wallsten 2005). The legacy of the electric telegraph often slowed network expansion. In Italy and Great Britain, for example, the government limited investment in the landline telephone to protect its investment in its telegraph network (Perry 1992; Fari 2008; Balbi 2011).

The landline telephone also differed from the electric telegraph in its relationship to its users. In the United States, the landline telephone would be technically and administratively reconfigured beginning around 1900 as a mass service for the entire population (John 2010: Ch. 8). In Europe, in contrast, with the partial exception of Sweden (Helgesson 1999), the medium would remain largely confined to an exclusive clientele until after the Second World War (Huurdeman 2003). The Soviet government proved to be particularly reluctant to permit the landline telephone to gain a foothold, fearful that it might prove subversive (Solnick 1991). Eventually, however, the landline telephone would find its way into homes as well as businesses in much of the industrialized world, making it the first telecommunications medium to foster new habits of sociability (Marvin 1988; Young 1991; Martin 1991; Fischer 1992; Kline 2000) that shifted the boundary between public and private (Bertho-Lavenir 1981; Flichy 1991). For Anglophone scholars, the sociological implications of this shift - a shift that until recently has been assumed to strengthen neither the family nor the group, but the individual - were clarified by the 1995 translation into English of Flichy's 1991 Une histoire de la communication moderne: Espace public et vie privée (Flichy 1995).

Two additional features of the early landline telephone are worth underscoring. First, the landline telephone was the first telecommunications network to presuppose real-time two-way communications. To minimize the call-connection delay, enterprising telephone managers invested heavily in manual telephone switchboards (John 2010: Ch. 7-8). If it took an excessive period of time to complete a connection, an interval that in the United States rapidly decreased in the 1880s and 1890s from minutes to seconds, users could be expected to seek out less time-consuming alternatives, such as the employment of a messenger, or even the scheduling of a face-to-face meeting. The heavy investment that American telephone companies made in manual switchboards slowed the transition to electromechanical (or automatic) switchboards. In several European countries, the 
transition from manual to electromechanical switchboards took even longer. In part for this reason, European telephone users came to associate the new medium with long wait times. Users waited not only for an open circuit, but also to be connected with a particular respondent once the circuit had been opened, and to be reconnected to their respondent should the open circuit fail. Criticism sometimes focused not on the limitations of the manual switchboards, but, rather, on the alleged laziness of the female telephone operators who operated them (Balbi 2013b).

A second notable feature of the landline telephone was its communicative bias. The landline telephone was the first telecommunications network that its users experienced primarily as an aural rather than a visual medium. Unlike the electric telegraph, it left no written trace. In 1877, Thomas A. Edison invented the phonograph to solve this problem. Edison envisioned the phonograph transforming a telephone call into a permanent record that would be analogous to a telegram (Gitelman 1999). In practice, however, the phonograph became a broadcast medium that was almost never used in conjunction with the telephone. (Telephone answering machines would not become commonplace until well after the Second World War).

The mobile telephone is often presumed to be a logical successor to the landline telephone, since, like the landline telephone, it facilitates real-time two-way communications. Yet if the mobile telephone is considered historically, then it can plausibly be contended that its most direct predecessor is not the landline telephone, but the wireless telegraph.

The wireless telegraph was the brainchild of Guglielmo Marconi, an Italianborn inventor of mixed Scottish-Italian ancestry. Marconi's fundamental innovation was to substitute for a wire network the air - that is, the electromagnetic spectrum, or what Marconi called the "ether." In so doing, he greatly decreased the cost of real-time point-to-point communication, since the greatest expense in the establishment of a wire network was the cost of its construction (Curien 2005).

The "killer app" for the early wireless telegraph was maritime logistics. Ships at sea were constantly in motion, making it impossible to link them into the already existing landline telegraph network. It was largely for this reason that the wireless telegraph received such lavish support from the British Admiralty, the German Navy, and the American Navy: no other communications network could match its flexibility (Friedewald 2000; Anduaga 2009; Evans 2010; Winkler 2008). By the 1910s, powerful nationally based corporations - Marconi in Great Britain, Telefunken in Germany, Société Général in France, and the Radio Corporation of America (RCA) in the United States - looked beyond maritime logistics to international communications (Griset 1996; Hugill 1999; Friedewald 2000). The wireless networks that the colonial powers established in this period were often the first telecommunications media to reach the more thinly settled and less economically developed parts of the world (Friedewald 2000; Winseck \& Pike 2007; Anduaga 
2009; Yang 2011). In so doing, these wireless networks linked localities that had yet to be reached by the hard-wired underwater cable corporations that were domiciled mostly in Great Britain (Headrick 1992; Finn \& Yang 2009). Wireless was cheaper (it was expensive to lay cables underwater) and harder to monopolize. By the Second World War, wireless telegraph (or radio) corporations had broken Britain's cable monopoly, while an upstart rival, the United States, had, by virtue of its large and powerful radio network, emerged as a major power in global telecommunications (Headrick 1994, 1995; Hugill 1999).

The wireless telegraph was the first new telecommunications network to emerge during the twentieth century. By mid-century it would be joined by radar and by the 1960s by satellites. Yet wireless point-to-point telecommunications would remain a specialty service for an exclusive clientele until the 1980s, with the rise of the mobile telephone.

The first successful mobile telephone network dates from 1977, when the American telecommunications provider American Telephone and Telegraph (AT\&T) demonstrated in Chicago an experimental wireless telephone. Two years later, the Japanese telecommunications provider Nippon Telephone and Telegraph (NTT) established in Tokyo the first mobile network that was open to users. Within five years, the NTT network would expand to cover all of Japan, making it the first nationwide first-generation (1G) network (Steinbock 2003). Similar ventures emerged at roughly the same time in Europe. In fact, Europe soon overtook the United States in mobile telephone penetration, a fact that, despite the emergence of an imaginative cohort of mobile telephone entrepreneurs (Galambos \& Abrahamson 2002), has remained true up to the present.

The expansion of mobile telephone networks in Europe was particularly notable, since it reversed a historical pattern. For much of the twentieth century, the United States had been the world's leading telecommunication provider. Now, in the century's waning years, Europe took the lead. One key development was the establishment in the early 1980s of the Nordic Mobile Telephone Group (NMT), a consortium that linked Denmark, Norway, Sweden, and Finland. NMT was the first mobile telephone network to make possible international roaming. Within a few years, NMT-designed protocols would become commonplace in more than forty countries in Europe and Asia, including Eastern Europe, Russia and Ukraine (Goggin 2006).

Equally consequential for the future was the establishment in Europe in December 1992 of a continental common standard: the Global System for Mobile Communication (GSM). This innovation, aptly dubbed a "bureaucratic miracle" (Agar 2013), was initially confined to 8 countries. Within four years, 103 countries, many of them outside Europe, had opted in. The GSM standard was far from universal. Other standards, for example, were introduced in the United States and Latin America. Yet GSM quickly became the world leader, facilitating a raft of technical improvements in signal quality and frequency management. Further 
innovations followed the rollout in the 1990s of the subscriber identity module (SIM) card, which enabled subscribers to authenticate their identity if they switched telephone devices, and, eventually, to retain a unique telephone number if they switched network providers.

The mobile telephone is by any measure one of the most significant innovations in media history. By 2013, 6.7 billion mobile-cellular telephone subscriptions had been entered into worldwide. The rapid adoption of the mobile telephone is particularly notable in those parts of the world in which access to telecommunications had previously been highly limited or even unknown. Of the 15 countries with the largest number of mobile telephone subscribers today, nine are in Asia (China, India, Indonesia, Pakistan, Japan, Bangladesh, Philippines, Iran and Asian Russia), two are in Latin America (Brazil and Mexico), and one is in Africa (Nigeria). The two countries with the world's largest number of mobile telephone subscribers - that is, China and India - had been, in the pre-mobile telephone era, telecommunications backwaters in which access had been confined to a tiny elite (Harwit 2008; Jeffrey \& Doron 2013). The present-day (2013) mobile-telephone penetration rate for both countries is impressive. In China, it hovers around 89 percent (1.2 billion telephones); in India, around 71 percent (886 million telephones). To be sure, these percentages overstate somewhat the telephone penetration rates in these countries, since well-to-do subscribers often have more than one mobile telephone. Even so, they testify to the rapidity with which this new medium has become a ubiquitous feature of everyday life in the developing world. Three other countries in which telecommunications had previously been little developed - namely, Russia, Indonesia, and Brazil - at present (2013) each boast collectively more than 200 million mobile telephone subscribers. From a global perspective, the mobile telephone has probably had its greatest impact in Africa, where it has enabled millions of people to talk at a distance for the first time in their lives. Its efficacy is probably enhanced by the oral nature of many African cultures (Hahn \& Kibora 2008), though mobile telephone penetration rates are high throughout the continent (de Bruijn, Nyamnjoh \& Brinkman 2009). The ubiquity of the mobile telephone raises challenging questions about the much-discussed digital divide: for millions of people around the world, the mobile telephone - rather than the computer monitor - is now the principal interface for connecting not only with other people, but also with the Internet.

\section{Three interpretative traditions}

The new perspective on the history of telecommunications that we sketched in the previous pages has been informed by three interpretative traditions: the history of technology; political economy; and social constructivism. To clarify our perspective, and to suggest avenues for future research, we believe it would be useful to 
detail some of the premises of these traditions, and to highlight some of the ways in which they have informed our analysis.

Historians of technology study communications networks in myriad ways. Some analyse the evolution of hardware; others the social context of invention. (Much of the English-language literature on these topics is cited in Sterling and Shiers 2000 and Sterling et al. 2006). Yet one approach - the large technical systems (or LTS) tradition - has proved for us to be particularly influential. While LTS ignores neither politics nor culture, it places particular emphasis on the internal logic of communications networks, and, in particular, their trajectory.

LTS comes in an American and a French variant (Balbi 2009). The American version was pioneered by historian Thomas P. Hughes; the French version - which is called "Macro-Systèmes Techniques" - by sociologist Alain Gras. For Hughes (1987), every large technical system has three components: technical contrivances; formal organizations; and rules. Gras reaches a parallel conclusion using somewhat different language. For him, the key components are industrial objects; complex organizations; and commercial intermediaries (Gras 1993, 1997).

Two of Hughes's key concepts (1987) are “momentum" and "load factor." The momentum of a large technical system is its propensity to become increasingly impervious to outside pressure, such as rivals or government regulation, as it expands. To adopt the language of the institutional economist, its evolution is path dependent: prior choices affect future outcomes. The load factor of a large technical system - as Hughes (1987) explains, using the electric power grid as his example - is the ratio of average output to maximum output during a specific time interval:

\footnotetext{
Best defined by a graph, or curve, the load factor traces the output of a generator, power plant, or utility system over a twenty-four-hour period. The curve usually displays a valley in the early morning, before the waking hour, and a peak in the early evening, when business and industry use power, homeowners turn on lights, and commuters increase their use of electrified conveyance. Showing graphically the maximum capacity of the generator, plant, or utility (which must be greater than the highest peak) and tracing the load curve with its peaks and valleys starkly reveals the utilization of capacity (Hughes 1987: 72).
}

One example of institutional momentum is the continuing reliance of French government administrators on the optical telegraph following the commercialization of the electric telegraph in Great Britain and the United States. The French optical telegraph by 1840 had fallen into what the economic historian Mark Elvin (1972) calls a "high-level equilibrium trap". Since it had operated effectively for half a century, its administrators proved reluctant to abandon it in favour of the new medium. Interestingly, the French would confront an analogous dilemma in the 1990s, when government engineers retained allegiance to Minitel, an early on-line network, slowing the rollout of the Internet (Schafer \& Thierry 2012). Once again, precocity proved to be an obstacle to change. A related example of institutional momentum has been the slow adoption of the mobile telephone in the United 
States. The United States in the 1980s boasted the finest landline telephone network in the world; predictably, the switchover to the mobile telephone network proved more halting than it would in China or India, countries that had never made a comparable investment. Various factors slowed the adoption of the mobile telephone in the United States. Potential users had already become accustomed to using pagers and electronic beepers, which provided some of the functionality that would come to be associated with the mobile telephone. Potential users were also frustrated by the available calling plans, which charged even for incoming calls. Network expansion was further constrained by poorly designed handsets and the existence of multiple, incompatible technical standards (Agar 2013: Ch. 1).

The load factor concept has proved useful in explaining the early history of the landline telephone, which was decisively shaped by the high cost of manual switching. For example, the diseconomies associated with the scaling up of the landline telephone network obliged enterprising late-nineteenth-century operating company managers such as Angus Hibbard of the Chicago Telephone Company to devise elaborate techniques to calculate load factors in telephone usage, a concept that Hibbard called the "telephone day" (John 2010: Ch. 8). All telecommunications managers, of course, must strike a balance between costs, network expansion, and network usage. Yet the management of the big-city landline telephone network in the era of manual switching posed an unusual challenge: every doubling in network size quadrupled the costs of making connections, giving managers an obvious incentive to keep their network small. Enterprising managers like Hibbard overcame this obstacle by rationalizing work flow, purchasing new switching equipment, and rolling out innovative marketing strategies and calling plans (John 2010: Ch. 8).

LTS can also help explain the relationship between telecommunications networks and the so-called "info-structure” (Joerges 1988: 24; Gras 1997: 31-33). Consider, for example, the relationship between the electric telegraph and the railroad in Great Britain and the United States (Schivelbusch 1987; Schwantes 2008; John 2010: Ch. 3). In both countries, railroad managers initially coordinated the movement of trains through personal observation. Following the commercialization of the electric telegraph, managers supplemented personal observations with data transmitted by electric telegraph. This switchover occurred much more quickly in Great Britain than in the United States. This was partly because British railroads were more highly capitalized than American railroads, and partly because of the conservatism of American railroad managers. Following the switchover, it became possible to greatly increase the movement of rolling stock on the rights-of-way. In fact, railroad engineers sometimes contended that a single-tracked railroad with telegraphic dispatching was more effective than a double-tracked railroad that continued to rely on personal observation (Schwantes 2008).

A second tradition that we have found to be particularly useful in writing the history of telecommunications networks has been political economy. Historical 
writing in this tradition is highly variegated, sometimes obscure, and occasionally tendentious (Mosco 2009). Two useful concepts are the structuring presence of rate-and-entry regulation, a relationship that has been analyzed by political scientist Robert B. Horwitz (1989), and the influence on business strategy of political structure, a relationship that has been explored by the economic historian Richard H. K. Vietor (1994).

The political economy tradition can help explain why telecommunications networks have evolved differently in different times and places. National styles are often a determining factor. Indeed, when historians of telecommunications networks adopt an international comparative perspective, they often discover that governmental institutions and civic ideals play a larger role in shaping network architecture than technology and economics (Moyal 1984; Galambos 1988; Starr 2004). Neither technology nor economics can explain why the French optical telegraph was a government monopoly while the British and American optical telegraphs were not. This outcome, rather, was a by-product of what the historical sociologist Paul Starr calls the "constitutive choices” of lawmakers (Starr 2004). It was, similarly, neither technology nor economics, but political fiat, that explains why government administrators in Switzerland, Belgium, Great Britain, France, and Germany configured the electric telegraph as a mass service for the entire population while corporate managers in the United States designed the electric telegraph as a specialty service for an exclusive clientele. Or, for that matter, why the Argentinian telegraph network ended up as a curious public-private hybrid (Hodge 1984). The very different trajectories of the landline telephone in Italy, Canada, Great Britain, and the United States, similarly, cannot be understood without emphasizing the influence on operating company managers of municipal franchise politics (Armstrong and Nelles 1986; Horwitz 1989; John 2008, 2010; Balbi 2011; McDougall 2013).

Even at the international level, politics mattered. Consider, for example, the Telegraph Union, later called the International Telecommunications Union (ITU). The establishment of the ITU in 1855 was shaped not only by technical considerations, but also by geopolitics, and in particular by the determination of Belgian administrators to challenge the prerogatives of the French emperor, Napoleon III (Laborie 2010). Large nations, of course, remained disproportionately influential in setting international standards (Feldman 1974; Griset 1999). Yet small nations such as Switzerland have also helped to devise network protocols and sometimes even to align organizational priorities with cherished national ideals such as neutrality and internationalism - as was demonstrated, for example, in the establishment of the Telegraph Union (Balbi et al. 2014).

Among the topics that can be illuminated by the political economy tradition is the propensity of telecommunications networks to become increasingly entrenched as their user base expanded, a phenomena that is often attributed in the Anglophone literature to "network effects" and in the Francophone literature 
to "effets de réseaux" or "effets de club." Telecommunications networks - unlike, say, gas or water networks - become (all things being equal) more valuable to individual users as they expand. This is because network expansion facilitates the linkage of a larger number of nodes. To be sure, one can point to historical instances in which telecommunications providers opposed network expansion as too costly, sometimes with the support of users unwilling to pay the higher rates that network expansion would bring (John 2010: Ch. 7). Even so, network expansion can develop a self-reinforcing logic that rewards early entrants, a phenomenon that has been analysed by many scholars, including the sociologist Manuel Castells (1996-1998) and the political theorist David Singh Grewal (2008).

The third and final tradition that we have found useful in our survey of the history of telecommunications networks is social constructivism (or SCOT, an acronym for the "social construction of technology"). Social constructivists highlight the extent to which technological artefacts, such as telecommunications networks, are built and maintained by social groups that include lawmakers, engineers, and managers. Among the social groups that the social constructivists devote special attention to are users, a group that other historians often neglect.

For the social constructivists, no analysis of a telecommunications network could pretend to be comprehensive if it failed to analyse the social matrix in which it was embedded, a matrix that included not only the social groups responsible for the construction, operation, and regulation of the network, but also the network's users. Each of these actors tries to shape the technology, with the outcome being a product of the resulting negotiation. The importance of social groups for the social constructivists was underscored in a celebrated essay by the sociologists Trevor Pinch and Wiebe Bijker (1984). Social scientists, they contend, should be mindful of all of the actors who contributed to the construction of a particular artefact, whether or not these social groups were insiders. What mattered, instead, were the mental maps that the actors shared: "The key requirement is that all members of a certain social group share the same set of meanings, attached to a specific artefact” (Pinch \& Bijker 1984: 414).

The influence of users for telecommunications networks has been widely documented. Users are important for at least two reasons. First, users sometimes invent applications for a network that its designers had not anticipated. The rollout of new communications networks is often accompanied by a great deal of uncertainty regarding its potential utility. The early landline telephone, for example, was sometimes configured not only as a one-to-one medium for personal communication, but also as a broadcast medium for music, news, and entertainment (Marvin 1988; Balbi 2010). In the case of the wireless telegraph, hobbyists popularized the controversial idea that a point-to-point medium might be transformed into a broadcast medium (Douglas 1989). And in the case of the mobile telephone, network managers failed to anticipate that text-messaging might be a popular feature until subscribers began to demonstrate its utility for social communication (Taylor \& Vin- 
cent 2005; Goggin 2011). Text-messaging is but one of the many unanticipated new social practices that the mobile telephone has spawned. Some of these social practices have attracted the attention of media sociologists, who contend that their ritual dimensions are fostering not the unbridled individualism predicted by media sociologists like Flichy (1991), but, instead, compelling new forms of social cohesion (Castells at al. 2007; Ling 2008).

Users are significant for a second reason. In certain instances, and contrary to a widespread assumption, they can block network expansion. In the case of the landline telephone, business users fearful that network expansion would increase rates and degrade the level of service to which they had become accustomed lobbied against the transformation of the medium from a specialty service for an exclusive clientele into a mass service for the entire population (John 2010: Ch. 7).

To understand the social consequences of the mobile telephone, it can be very useful to adopt a user-centric lens. To an extent that may well be unmatched by any previous telecommunications medium, with the possible exception of the early landline telephone (Kline 2000), mobile telephone users have proved ingenious in devising unanticipated uses for the medium. In India, fishermen, factory workers, and farmers are using the mobile telephone to improve their ability to compete in the marketplace (Jensen 2007; Jeffrey \& Doron 2013). In Russia, nomadic reindeer hunters are using the medium to remain in touch with their families (Stammler 2009). And in Kenya, urbanites use the mobile telephone as an electronic wallet to send money to friends and family members in distant villages - a convenience called M-PESA ("M" stands for mobile; "PESA" is the word for money in Swahili) that is highly valued in a country in which reliable cash machines are few and far between (Agar 2013: Ch. 16). Even so, a single-minded focus on the user can be misleading. It is a mistake, for example, to conflate the proliferation of the mobile telephone with a concomitant increase in the power (or "agency") of users to increase their autonomy. In fact, as Italian scholar Michela Nacci (2000) has posited, this conflation owes much to what she terms the "transparency paradox." Mobile telephone users interact primarily with their own, often highly personalized, mobile devices, which can lead them to underestimate the vulnerability of their on-line behaviour to data mining by businesses, governments, and other individuals. As a consequence, they can easily exaggerate their autonomy and underestimate the extent to which they are subject to mental manipulation by marketers, scam artists, or even sexual predators. Network managers often conceal the full extent of this electronic surveillance from users for two reasons: first, to simplify their interaction with the network; and, second, to lull them into giving the network their unqualified trust.

Closely related to yet distinct from social constructivism is cultural studies, a convenient shorthand term for scholarship that focuses on the ideational dimensions of historical phenomena. While many social constructivists distance themselves from cultural studies, the two traditions share an interest in social relation- 
ships, ideology, and group identity. This tradition has been particularly fruitful for historians interested in gaining critical perspective on the rhetoric deployed by promoters, popularizers, and publicists. To a greater extent than historians of technology who focus on large technical systems or political economy, these scholars are attentive to issues of language and rhetoric. Among its most distinguished practitioners have been the British sociologist Raymond Williams (1974); the West Indian-born Anglophone social theorist Stuart Hall (1980); the American literary critic Leo Marx (1994, 2010); and the American communications scholar James W. Carey (1989).

The cultural studies tradition has provided historians of communications with the tools to gain a critical perspective on fundamental, yet sometimes implicit, values and norms. For example, the ideological currents that shaped networkbuilding in France have been probed by Armand Matterlart (1992, 2000), Rosalind Williams (1993), and Pierre Musso (1997). In a similar vein, the mythologizing of the mobile telephone as a spiritual - and, indeed, transcendent medium - has been sketched by James E. Katz (2006) and Rich Ling (2008). The ideology of "universal service"- long an influential norm for telecommunications providers in the United States - is clarified by recognizing its embeddedness in a cultural discourse, as are such seemingly commonsensical ideas as the "invention" of blockbuster devices such as the electric telegraph or the telephone, the establishment of global telecommunications networks, and the transformation of the telephone from a specialty service for the few into a mass service for the entire population (John 2010; Hampf \& Müller-Pohl 2013; McDougall 2013; Beauchamp 2014).

\section{Conclusion}

The rapid emergence of the mobile telephone in the past several decades has fundamentally altered not only the present and future of telecommunications but also its past. To render this past intelligible, we have surveyed the history of four point-to-point networks - the optical telegraph, the electric telegraph, the landline telephone, and the mobile telephone - using different interpretative traditions the history of technology, political economy, and social constructivism. No longer can it plausibly be assumed that telecommunications is a detour on the road toward broadcasting or that the computer monitor (as distinct from the mobile telephone) will remain the primary digital interface for the world's netizens. The commercialization of the Internet, the convergence between broadcast and pointto-point media, and the proliferation of the mobile telephone all underscore the indispensability of point-to-point networks to public and private life. To understand today's media ecology and the digital culture it has spawned, we need to know how and why these networks emerged. 


\section{References}

Agar, Jon. 2013. Constant touch: A global history of the mobile phone. Rev. ed. Cambridge: Icon Books.

Anduaga, Aitor. 2009. Wireless and empire: Geopolitics, radio industry, and ionosphere in the British Empire, 1918-1939. Oxford: Oxford University Press.

Armstrong, Christopher \& H. V. Nelles. 1986. Monopoly's moment: The organization and regulation of Canadian utilities, 1830-1930. Philadelphia: Temple University Press.

Baark, Erik. 1997. Lightning wires: The telegraph and China's technological modernization, 18601890. Westport, CT: Greenwood Press.

Balbi, Gabriele. 2009. Studying the social history of telecommunications: Between Anglophone and continental traditions. Media Histo 15. 85-101.

Balbi, Gabriele. 2010. Radio before radio: Araldo telefonico and the invention of Italian broadcastsing. Technology and Culture 41. 786-808.

Balbi, Gabriele. 2011. The origins of the telephone in Italy, 1877-1915: Politics, economics, technology, and society. International Journal of Communications 5. 1058-1081.

Balbi, Gabriele. 2013a. Telecommunications. In Peter Simonson, Janis Peck, Robert Craig, \& John Jackson (eds.), Handbook of communication history, 209-222. London: Routledge.

Balbi, Gabriele. 2013b. 'I will answer you, my friend, but I am afraid': Telephones and the fear of a new medium in nineteenth and early twentieth-century Italy. In Siân Nicholas \& Tom 0'Malley (eds.), The media, social fears and moral panics: Historical perspectives, 59-75. London and New York: Routledge.

Balbi, Gabriele, with Simone Fari, Giuseppe Richeri \& Spartaco Calvo. 2014. Network neutrality: Switzerland's role in the genesis of the Telegraph Union, 1855-1875. Bern: Peter Lang.

Barabási, Albert-Laszlo. 2002. Linked: The new science of networks. Cambridge, MA: Perseus Publishing.

Beauchamp, Christopher. 2014. Invented by law: Alexander Graham Bell and the patent that changed America. Cambridge, MA: Harvard University Press.

Bektas, Yakup. 2000. The sultan's messenger: Cultural constructions of Ottoman telegraphy, 1847-1880. Technology and Culture 41. 669-696.

Bertho-Lavenir, Catherine. 1981. Télégraphes et téléphones: de Valmy au microprocesseur. Paris: Livre de Poche.

Bertho-Lavenir, Catherine. 1988. The telephone in France 1879-1979: National characteristics and international influences. In Renate Mayntz \& Thomas P. Hughes (eds.), The development of large technical systems, 155-177. Boulder: Westview Press.

Blondheim, Menahem. 1994. News over the wires: The telegraph and the flow of public information in America, 1844-1897. Cambridge MA: Harvard University Press.

de Bruijn, Mirjam, Nyamnjoh, Francis \& Inge Brinkman (eds.). 2009. Mobile phones: the new talking drums of everyday Africa. Langaa, Bamenda (Cameroon); African Studies Centre, Leiden (the Netherlands).

Calvo, Angel. 2002. The Spanish telephone sector (1876-1924): A case of technological backwardness. History and Technology 18. 77-102.

Calvo, Angel. 2006. The shaping of urban telephone networks in Europe, 1877-1926. Urban History 33. 411-433.

Carey, James. W. 1989. Communication as culture: Essays on media and society. Boston: Unwin Hyman.

Castells, Manuel. 1996-1998. The Information age: Economy, society and culture. 3 Vols. Oxford: Blackwell.

Castells, Manuel, Mireia Fernández-Ardèvol, Jack Linchuan Qiu \& Araba Sey. 2007. Mobile communication and society: A global perspective. Cambridge, MA: MIT Press. 
Curien, Nicolas. 2005. Economie des réseaux. Paris: Découverte.

De Wit, Onno. 1998. Telefonie in Nederland, 1877-1940. Den Haag: Cramwinckel.

Douglas, Susan. J. 1989. Inventing American broadcasting, 1899-1922. Baltimore: Johns Hopkins University Press.

Downey, Gregory John. 2002. Telegraph messenger boys: Labor, technology, and geography, 1850-1950. New York: Routledge.

Elvin, Marc. 1972. The high-level equilibrum trap: The causes of the decline of invention in traditional Chinese textile industries. In William E. Willmott (ed.), Economic organization in Chinese society, 137-172. Stanford: Stanford University Press.

Evans, Heidi J. S. 2010. 'The path to freedom?' Transocean and German wireless telegraphy, 1914-1922. Historical Social Research, 35, 209-233.

Fari, Simone. 2008. Una penisola in comunicazione: Il servizio telegrafico italiano dall'Unità alla Grande Guerra. Bari: Cacucci Editore.

Feldman, Mildred. L. B. 1974. The United States in the International Telecommunication Union and in pre-ITU conferences: Submarine cables, overland telegraph, sea and land radio, telecommunications. Baton Rouge: n. p.

Finn, Bernard \& Daging Yang (eds.). 2009. Communications under the seas: The evolving cable network and its implications. Cambridge, MA: MIT Press.

Fischer, Claude S. 1992. America calling: A social history of the telephone to 1940. Berkeley: University of California Press.

Flichy, Patrice. 1991. Une histoire de la communication moderne: espace public et vie privée. Paris: Decouverte.

Flichy, Patrice. 1995. Dynamics of modern communication: The shaping and impact of modern communication technologies. Liz Libbrecht (trans.). New York: SAGE.

Friedewald, Michael. 2000. The beginnings of radio communication in Germany, 1897-1918. Journal of Radio Studies 7. 441-462.

Gabel, David. 1995. Federalism: An historical perspective. In Paul Teske (ed.), American regulatory federalism and telecommunications infrastructure, 19-31. Hillsdale, NJ: Lawrence Erlbaum Associates.

Galambos, Louis. 1988. Looking for the boundaries of technological determinism: A brief history of the U.S. telephone system. In Renate Mayntz \& Thomas P. Hughes (eds.), The development of large technical systems, 135-153. Boulder: Westview Press.

Galambos, Louis \& Eric J. Abrahamson. 2002. Anytime, anywhere: Entrepreneurship and the creation of a wireless world. Cambridge: Cambridge University Press.

Gitelman, Lisa. 1999. Scripts, grooves, and writing machines: Representing technology in the Edison era. Stanford: Stanford University Press.

Goggin, Gerard. 2006. Cell phone culture: mobile technology in everyday life. London: Routledge.

Goggin, Gerard. 2011. Global mobile media. London: Routledge.

Gras, Alain. 1993. Grandeur et dépendance: sociologie des macro-systèmes techniques. Paris: Presses universitaires de France.

Gras, Alain. 1997. Les macro-systèmes techniques. Paris: Puf.

Grewal, David Singh. 2008. Network power: The social dynamics of globalization. New Haven: Yale University Press.

Griset, Pascal. 1996. Technologie, entreprise, et souveraineté: Les télécommunications transatlantiques de la France. Paris: Rive-Droite.

Griset, Pascal. 1999. Technical system and strategy: Intercontinental telecommunications in the first quarter of the twentieth century. In Olivier Coutard (ed.), The governance of large technical systems, 58-72. London: Routledge.

Hall, Stuart. 1980. Encoding/decoding. In Stuart Hall, Dorothy Hobson, Andrew Lowe, \& Paul Willis (eds.), Culture, media, language: Working papers in cultural studies 1972-79, 128138. London: Hutchinson. 
Hampf, M. Michaela \& Simone Müller-Pohl (eds.). 2013. Global communication electric: Business, news, and politics in the world of telegraphy. Chicago: University of Chicago Press.

Hahn, Hans Peter \& Ludovic Kibora. 2008. The domestication of the mobile phone: Oral society and new ICT in Burkina Faso. Journal of Modern African Studies 46. 87-109.

Harwit, Eric. 2008. China's telecommunications revolution. Oxford: Oxford University Press.

Hazlewood, Arthur. 1953. The origin of the state telephone service in Britain. Oxford Economic Papers, new series 5. 13-25.

Headrick, Daniel R. 1988. The tentacles of progress: Technology transfer in the age of imperialism, 1850-1940. New York: Oxford University Press.

Headrick, Daniel R. 1992. The invisible weapon: Telecommunications and international politics, 1851-1945. New York: Oxford University Press.

Headrick, Daniel R. 1994. Shortwave radio communication and its impact on international telecommunications between the wars. History and Technolog 11. 21-32.

Headrick, Daniel R. 1995. Public-private relations in international telecommunications before World War II. In Bella Mody, Johannes M. Bauer \& Joseph D. Straubhaar (eds.), Telecommunications politics: Ownership and control of the information highway in developing countries, 31-49. Hillsdale, NJ: Lawrence Erlbaum Associates.

Headrick, Daniel R. 2000. When information came of age: Technologies of knowledge in the age of reason and revolution, 1700-1850. Oxford: Oxford University Press.

Helgesson, Claes-Fredrik. 1999. Making a natural monopoly: The configuration of a technoeconomic order in Swedish telecommunications. Stockholm: Stockholm School of Economics.

Hermans, Janneke \& Onno De Wit. 2004. Bourses and brokers: stock exchanges as ICT junctions. History and Technology 20. 227-247.

Herring, James Morton, \& Gerald Connop Gross. 1936. Telecommunications: Economics and regulation. New York: McGraw-Hill.

Hochfelder, David. 2012. The telegraph in America, 1832-1920. Baltimore: Johns Hopkins University Press.

Hodge, John E. 1984. The role of the telegraph in the consolidation and expansion of the Argentine Republic. The Americas 41. 59-80.

Holzmann, Gerard. J. \& Bjorn Pehrson 1995. The early history of data networks. Hoboken, NJ: John Wiley \& Sons.

Horwitz, Robert Britt. 1989. The irony of regulatory reform: The deregulation of American telecommunications. New York: Oxford University Press.

Hughes, Thomas P. 1987. The evolution of large technical systems. In Thomas P. Hughes \& Trevor Pinch (eds.), The social construction of technological systems, 51-82. Cambridge MA: MIT Press.

Hugill, Peter J. 1999. Global communications since 1844: geopolitics and technology. Baltimore: Johns Hopkins University Press.

Huurdeman, Anton. 2003. The worldwide history of telecommunications. Hoboken, NJ: John Wiley \& Sons.

Jeffrey, Robin \& Assa Doron. 2013. The great Indian phone book: How the cheap cell phone changes business, politics, and daily life. Cambridge, MA: Harvard University Press.

Jensen, Robert. 2007. The digital provide: Information (technology), market performance, and welfare in the south Indian fisheries sector. Quarterly Journal of Economic, 122. 879-924.

Joerges, Bernward. 1988. Large technical systems: Concepts and issues. In Renate Mayntz \& Thomas P. Hughes (eds.), The development of large technical systems, 9-36. Boulder: Westview Press.

John, Richard R. 1995. Spreading the news: The American postal system from Franklin to Morse. Cambridge, MA: Harvard University Press. 
John, Richard R. 2008. Telecommunications. Enterprise and Society 9. 507-520.

John, Richard R. 2010. Network nation: Inventing American telecommunications.

Cambridge: Belknap Press of Harvard University Press.

John, Richard R. 2013. Communications networks in the United States from Chappe to Marconi. In Angharad N. Valdivia (ed.), International Encyclopedia of Media Studies, 310-332. Oxford: Blackwell.

Katz, James Everett. 2006. Magic in the air: Mobile communication and the transformation of social life. New Brunswick, NJ: Transaction.

Kieve, Jeffrey. 1973. The electric telegraph: A social and economic history. Devon: David and Charles Newton Abbot.

Kline, Ronald B. 2000. Consumers in the country: Technology and social change in rural America. Baltimore: Johns Hopkins University Press.

Kobelt, C. 1980. One-hundred years of telephone service in Switzerland. Bulletin Technique PTT 10. 344-363.

Laborie, Léonard. 2010. L'Europe mise en réseaux: La France et la coopération internationale dans les postes et les télécommunications (années 1850-années 1950). Bern: Peter Lang.

Ling, Richard Seyler. 2008. New tech, new ties: How mobile communication is reshaping social cohesion. Cambridge, MA: MIT Press.

Martin, Michèle. 1991. 'Hello central?’: Gender, technology, and culture in the formation of telephone systems. Montréal: McGill-Queen's University Press.

Marvin, Carolyn. 1988. When old technologies were new: Thinking about electric communication in the late nineteenth century. New York: Oxford University Press.

Marx, Leo. 1994. The idea of 'technology' and postmodern pessimism. In Merrit Roe Smith \& Leo Marx (eds.), Does technology drive history? The dilemma of technological determinism, 237258. Cambridge, MA: MIT Press.

Marx, Leo. 2010. Technology: The emergence of a hazardous concept. Technology and Culture 51. 561-577.

Matterlart, Armand. 1992. La communication-monde: Histoire des idées et des stratégies. Paris: Découverte.

Matterlart, Armand. 2000. Networking the world, 1794-2000. J. A. Cohen and L. Carey-Libbrecht (trans.). Minneapolis: University of Minnesota Press.

Mayntz, Renate and Thomas P. Hughes (eds.). 1988. The development of large technical systems. Boulder: Westview Press.

McChesney, Robert W. 1993. Telecommunications, mass media, \& democracy: The battle for control of U.S. broadcasting, 1928-1935. New York: Oxford University Press.

McDougall, Robert. 2013. The people's network: The political economy of the telephone in the gilded age. Philadelphia: University of Pennsylvania Press.

Millward, Robert. 2005. Private and public enterprise in Europe: Energy, telecommunications, and transport, 1830-1990. Cambridge: Cambridge University Press.

Mosco, Vincent. 2009. The political economy of communication. London: Sage.

Moyal, Ann. 1984. Clear across Australia: A history of telecommunications. Melbourne: Nelson.

Musso, Pierre. 1997. Télécommunications et philosophie des réseaux: la postérité paradoxale de Saint-Simon. Paris: Presses universitaires de France.

Nacci, Michela. 2000. Pensare la tecnica: Un secolo di incomprensioni. Roma-Bari: Laterza.

Noam, Eli M. 1992. Telecommunications in Europe. New York: Oxford University Press.

Noam, Eli M. (ed.). 1999. Telecommunications in Africa. New York: Oxford University Press.

Perry, C. R. 1992. The Victorian post office: The growth of a bureaucracy. Suffolk, England: Boydell Press.

Pinch, Trevor \& Wiebe E. Bijker. 1984. The social construction of facts and artefacts: Or how the sociology of science and the sociology of technology might benefit each other. Social Studies of Science 14. 399-441. 
Rosenfeld, Sophia. 2001. A revolution in language: the problem of signs in late eighteenthcentury France. Stanford, CA: Stanford University Press.

Schafer, Valérie \& Benjamin G. Thierry. 2012. Le Minitel: l'enfance numérique de la France. Paris: Nuvis.

Schivelbusch, W. 1987. The railway journey: The industrialization of time and space in the nineteenth century. Berkeley: University of California Press.

Schneider, Volker. 1991. The governance of large technical systems: The case of telecommunications. In Tedd R. L. Porte (ed.), Social responses to large technical systems: Control or anticipation, 19-41. Dordrecht: Kluwer Academic Publishers.

Schwantes, Benjamin. 2008. Fallible guardian: The social construction of railroad telegraphy in nineteenth-century America. Unpublished doctoral dissertation. University of Delaware, Newark, DE.

Solnick, Steven. L. 1991. Revolution, reform and the Soviet telephone system, 1917-1927. Soviet Studies 43. 157-175.

Stammler, Florian. M. 2009. Mobile phone revolution in the tundra? Technological change among Russian nomads. Folklore 41. 47-78.

Starr, Paul. 2004. The creation of the media: Political origins of modern communications. New York: Basic Books.

Steinbock, Dan. 2003. Wireless horizon: Strategy and competition in the worldwide mobile marketplace. New York: AMACON.

Sterling, Christopher H. \& George Shiers. 2000. History of telecommunications technology: An annotated bibliography. Lanham, MD: Scarcecrow Press.

Sterling, Christopher, Phyllis Bernt \& Martin B. H. Weiss. 2006. Shaping American telecommunications: A history of technology, policy, and economics. Hillsdale, NJ: Lawrence Erlbaum Associates.

Taylor, Alex S. \& Jane Vincent. 2005. An sms history. In Lynne Hamil \& Amparo Larsen (eds.), Mobile world: Past, present and future, 75-91. London: Springer.

Thomas, Frank. 1988. The politics of growth: The German telephone system. In Renate Mayntz and Thomas P. Hughes (eds.), The development of large technical systems, 179-213. Boulder: Westview Press.

Vietor, Richard. 1994. Contrived competition: Regulation and deregulation in America. Cambridge: Cambridge University Press.

Wallsten, Scott. 2005. Returning to Victorian competition, ownership, and regulation: An empirical study of European telecommunications at the turn of the twentieth century. Journal of Economic History 65. 693-722.

Weiman, David F. 2003. Building 'universal service' in the early Bell system: The co-evolution of regional urban systems and long distance telephone networks. In William Sundstrom, Timothy W. Guinnane \& Warren C. Whatley (eds.), History matters: Essays on economic growth, technology, and demographic change, 328-33. Stanford, CA: Stanford University Press.

Williams, Raymond. 1974. Television: Technology and cultural form. London: Fontana.

Williams, Rosalind. 1993. Cultural origins and environmental implications of large technological systems, Science in Context 6. 377-403.

Wilson, Geoffrey. 1976. The old telegraphs. London: Phillimore.

Winkler, Jonathan Reed. 2008. Nexus: Strategic communications and American security in World War I. Cambridge, MA: Harvard University Press.

Winseck, Dwayne R. \& Robert M. Pike. 2007. Communication and empire: Media, markets, and globalization, 1860-1930. Durham: Duke University Press.

Wolff, Joshua D. 2013. Western Union and the creation of the American corporate order, 18451893. Cambridge: Cambridge University Press. 
Yang, Daqing. 2011. Technology of empire: Telecommunications and Japanese expansion in Asia, 1883-1945. Cambridge, MA: Harvard University Press.

Young, Peter. 1991. Person to person: The international impact of the telephone. Cambridge: Granta. 